\title{
Revised D-A-CH Reference Values for the Intake of Vitamin $B_{6}$
}

\author{
Alexandra Jungert ${ }^{a}$ Jakob Linseisen $^{b, c}$ Karl-Heinz Wagner ${ }^{d}$ Margrit Richter $^{e}$ \\ On Behalf of the German Nutrition Society (DGE)
}

anterdisciplinary Research Center for Biosystems, Land Use and Nutrition (IFZ), Biometry and Population Genetics,

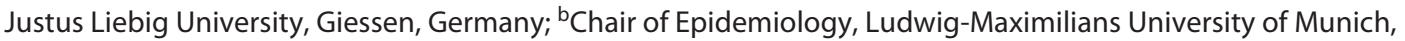
Augsburg, Germany; ${ }^{c}$ Clinical Epidemiology, Helmholtz Zentrum München (HMGU), Neuherberg, Germany; dDepartment of Nutritional Sciences, University of Vienna, Vienna, Austria; 'Department of Science, German Nutrition Society (DGE), Bonn, Germany

\section{Keywords}

Vitamin $B_{6}$. Reference values · Recommended intake .

Human nutrition

\begin{abstract}
Background: The Nutrition Societies of Germany, Austria, and Switzerland as the joint editors of the "D-A-CH reference values for nutrient intake" have revised the reference values for vitamin $B_{6}$ in summer 2019. Summary: For women, the average requirement $(A R)$ for vitamin $B_{6}$ intake was derived on the basis of balance studies using a pyridoxal-5'phosphate (PLP) plasma concentration of $\geq 30 \mathrm{nmol} / \mathrm{L}$ as a biomarker of an adequate vitamin $B_{6}$ status. The recommended intake (RI) was derived considering a coefficient of variation of $10 \%$. The RIs of vitamin $B_{6}$ for men, children, and adolescents were extrapolated from the vitamin $B_{6}$ requirement for women considering differences in body weight, an allometric exponent, growth factors as appropriate, and a coefficient of variation. For infants aged 0 to under 4 months, an estimated value was set based on the vitamin $B_{6}$ intake via breast feeding. The reference value for infants aged 4 to under 12 months was extrapolated from the estimated value for infants under 4 months of age and the average vitamin $B_{6}$ requirement for adults. The reference values for pregnant
\end{abstract}

karger@karger.com www.karger.com/anm

Karger $\frac{1}{\%}$

GOPEN ACCESS
(C) 2020 The Author(s)

Published by S. Karger AG, Basel

This article is licensed under the Creative Commons AttributionNonCommercial-NoDerivatives 4.0 International License (CC BYNC-ND) (http://www.karger.com/Services/OpenAccessLicense). Usage and distribution for commercial purposes as well as any distribution of modified material requires written permission. and lactating women consider the requirements for the foetus and the loss via breast milk. Key Messages: According to the combined analysis of 5 balance studies, the AR for vita$\min B_{6}$ to ensure a plasma PLP concentration of $\geq 30 \mathrm{nmol} / \mathrm{L}$ is $1.2 \mathrm{mg} /$ day for adult females and the extrapolated AR for adult males is $1.3 \mathrm{mg} /$ day. The corresponding Rls of vitamin $\mathrm{B}_{6}$ are $1.4 \mathrm{mg} /$ day for adult females and $1.6 \mathrm{mg} /$ day for adult males, independent of age. For infants, the estimated value is $0.1 \mathrm{mg} /$ day and $0.3 \mathrm{mg} /$ day, depending on age. The AR of vitamin $B_{6}$ for children and adolescents ranges between 0.5 and $1.5 \mathrm{mg} /$ day, and the Rl is between $0.6 \mathrm{mg} /$ day and 1.6 $\mathrm{mg} /$ day. During pregnancy, the AR is $1.3 \mathrm{mg} /$ day in the first trimester and $1.5 \mathrm{mg} /$ day in the second and third trimesters; the $\mathrm{Rl}$ is $1.5 \mathrm{mg} /$ day in the first trimester and $1.8 \mathrm{mg} /$ day in the second and third trimesters. For lactating women, the AR is $1.3 \mathrm{mg} /$ day and the $\mathrm{Rl}$ is $1.6 \mathrm{mg} /$ day.

(c) 2020 The Author(s)

Published by S. Karger AG, Basel

\section{Introduction}

\section{Reference Values for Nutrient Intake}

The D-A-CH "reference values for nutrient intake" [1] are jointly issued by the Nutrition Societies of Germany, Austria, and Switzerland (the abbreviation D-A-CH aris- 
es from the initial letters of the common country identification for the countries Germany [D], Austria [A], and Switzerland $[\mathrm{CH}]$ ). Reference value is a collective term for recommended intake (RI), estimated values, and guiding values. The starting point for the derivation of reference values is the determination of the average requirement (AR). The experimentally ascertained AR assumes to meet the needs of the daily nutrient intake of $50 \%$ of a defined group of people. For the derivation of the RI, 20$30 \%$ is added to the AR what corresponds to 2 standard deviations or a variation coefficient of $10-15 \%$. Thus, a RI value, according to its definition, meets the requirement of nearly any person (approximately 98\%) of sex- and age-stratified population groups. Estimated values are given when human requirements cannot be determined with desirable accuracy. Guiding values are given as orientation $[1,2]$.

Reference values for nutrient intake are amounts that are assumed to

- protect nearly all healthy individuals in a population from deficiency-related conditions,

- ensure optimal physiological and psychological performance, and

- create a certain body reserve [1].

The reference values should be revised regularly. Since 2012, the D-A-CH nutrition societies have published revised reference values for the intake of several nutrients [3-13] but not yet for vitamin $\mathrm{B}_{6}$. The last update of the reference values for vitamin $\mathrm{B}_{6}$ given by the $\mathrm{D}-\mathrm{A}-\mathrm{CH}$ nutrition societies dates to a report in 2000 [14]. In summer 2019 , the revised reference values for vitamin $B_{6}$ intake were published in German. This paper provides a summary of this work.

\section{Vitamin $B_{6}$}

Vitamin $B_{6}$ is one of the water-soluble vitamins [15]. The term refers to a group of 2-methyl-3-hydroxy-5-hydroxymethyl pyridine compounds with pyridoxine activity, including pyridoxine $(\mathrm{PN})$, pyridoxamine $(\mathrm{PM})$, and pyridoxal (PL) as well as their phosphoric acid esters pyridoxine $5^{\prime}$-phosphate (PNP), pyridoxamine $5^{\prime}$-phosphate (PMP), and pyridoxal 5' -phosphate (PLP) [16].

Physiologically, PLP and PMP function as cofactors for enzymes of the amino acid metabolism [16]. In addition, vitamin $\mathrm{B}_{6}$ plays a role in metabolism of carbohydrates [17], conversion of niacin to tryptophan [18], and synthesis of sphingolipids [19], 5-aminolevulinic acid (a precursor of haemoglobin) [20], and neurotransmitters [21]. Together with riboflavin, folate, and cobalamin, vitamin $B_{6}$ regulates homocysteine metabolism [22]. In this context, PLP is required for the conversion of 5,10-methylenetetrahydrofolate from tetrahydrofolate and thus for the remethylation of homocysteine to methionine [22]. Within the transsulfuration pathway, vitamin $B_{6}$ is involved in the degradation of homocysteine to cysteine [22].

The vitamin $\mathrm{B}_{6}$ content in foods was found to be affected by freezing, cooking, and further processing, albeit the extent of the losses varied depending on the assessed compound [23]. The absorption rate of vitamin $\mathrm{B}_{6}$ depends on the diet. Vitamin $B_{6}$ from animal-based foods has a higher bioavailability than vitamin $B_{6}$ from plantbased foods [24] due to the lower bioavailability of pyridoxine- $5^{\prime}-\beta$-d-glucoside (PNG) found in plant-based foods compared to PN [24-26]. The estimated bioavailability of free $\mathrm{PN}$ is $\geq 95 \%[27,28]$, while the average bioavailability of PNG is $50-58 \%[25,26]$. Depending on the kind of food, the PNG proportion of the total vitamin $\mathrm{B}_{6}$ content ranges between 0 and $82 \%$ [24]. With a mixed diet containing $2.3 \mathrm{mg}$ of vitamin $\mathrm{B}_{6}$ per day, the average absorption rate of vitamin $B_{6}$ is $75 \%$, based on measurements of plasma PLP concentration and 24-h urinary vitamin $B_{6}$ excretion in men [27].

The average vitamin $\mathrm{B}_{6}$ pool in the human body is estimated to be $\sim 1,000 \mu \mathrm{mol}(167 \mathrm{mg}$ ), whereupon up to $80 \%$ of the vitamin $\mathrm{B}_{6}$ is located in the muscle $[29,30]$. The majority of vitamin $B_{6}$ in the muscle is found as PLP bound to glycogen phosphorylase [21, 29]. The vitamin $\mathrm{B}_{6}$ pool in muscle is relatively stable, even at a low-vitamin $\mathrm{B}_{6}$ diet for 6 weeks [31]. In plasma, vitamin $\mathrm{B}_{6}$ exists primarily as PLP [32] bound to albumin [33]. In erythrocytes, PLP binds to haemoglobin [16]. Free PLP can be dephosphorylated by alkaline phosphatase to PL, which is capable of crossing biological membranes [16].

There is a sigmoidal relationship between vitamin $B_{6}$ intake and plasma PLP concentration [27]. Plasma PLP concentration reaches a new equilibrium $\sim 10$ days after PN supplementation [34] or about 14 days after changing dietary vitamin $\mathrm{B}_{6}$ intake [27]. The half-life of vitamin $\mathrm{B}_{6}$ is 2-6 weeks; around $2-3 \%$ of the vitamin $B_{6}$ pool are lost per day [35]. 4-Pyridoic acid (4-PA) is the major catabolic metabolite with a proportion of up to $85 \%$ of the total vitamin $B_{6}$ excretion via urine [34].

\section{Criteria to Assess the Supply with Vitamin $B_{6}$}

Vitamin $\mathrm{B}_{6}$ status can be determined directly by biomarkers, for example, concentrations of PL, PMP, or PLP in plasma or erythrocytes, and total vitamin $\mathrm{B}_{6}$ or $4-\mathrm{PA}$ 
concentrations in urine [16]. Currently, plasma PLP concentration is considered to be the best status parameter [28]. It correlates with both vitamin $B_{6}$ intake [36-38] and vitamin $B_{6}$ concentration in tissue [34]. A deficient vitamin $B_{6}$ status is assumed for PLP concentrations $<20$ $\mathrm{nmol} / \mathrm{L}$. PLP concentrations between 20 and $30 \mathrm{nmol} / \mathrm{L}$ indicate a marginal status and PLP concentrations $>30$ $\mathrm{nmol} / \mathrm{L}$ an adequate supply [39]. In intervention studies in healthy subjects who received a low-vitamin $\mathrm{B}_{6}$ diet $\left(<0.5 \mathrm{mg}\right.$ vitamin $\mathrm{B}_{6}$ per day), changes in the amino acid profile and in the metabolism of one-carbon units and tryptophan occurred at PLP concentrations $<30 \mathrm{nmol} / \mathrm{L}$ $[39,40]$. It has to be considered that inflammation [4143], a low albumin concentration, and a high alkaline phosphatase activity may have a negative impact on PLP concentration [16]. Lifestyle factors like smoking and alcohol intake are considered to be influencing factors as well [43-45]. Current and former smokers show frequently lower PLP concentrations than subjects who had never smoked what might be a result of oxidative stress caused by smoking [43]. Some studies reported a positive association between vitamin $B_{6}$ status parameters and alcohol consumption $[46,47]$. This observation might be explained by a higher vitamin $\mathrm{B}_{6}$ intake due to the consumption of alcoholic beverages or changes in transsulfuration and methylation processes [46]. In contrast, chronic alcohol abuse is associated with lower PLP concentrations [44], probably due to an impairment of liver function [45].

Since vitamin $\mathrm{B}_{6}$ is important for amino acid metabolism, it was proposed that the requirement for vitamin $\mathrm{B}_{6}$ is linked to protein intake [48]. However, due to inconsistent results, different study designs, and varying protein intake levels [48-52], no influence of protein intake on vitamin $\mathrm{B}_{6}$ requirements of subjects following a usual mixed diet is assumed.

\section{Derivation of the Reference Values for the Intake of Vitamin $B_{6}$}

\section{Adults}

Adults under 65 Years of Age

The reference values for vitamin $B_{6}$ intake in adults under 65 years of age were derived based on the intake levels that are required for a plasma PLP concentration of $\geq 30 \mathrm{nmol} / \mathrm{L}$. According to the results of intervention studies, daily intakes of $1.3-1.5 \mathrm{mg}$ vitamin $\mathrm{B}_{6}$ are sufficient to achieve a PLP concentration of $\geq 30 \mathrm{nmol} / \mathrm{L}$ in the majority of women, even at a daily protein intake of 1.2
Table 1. Recommended intake values for vitamin $B_{6}$

\begin{tabular}{|c|c|c|}
\hline \multirow[t]{2}{*}{ Age } & \multicolumn{2}{|c|}{ Vitamin $\mathrm{B}_{6}, \mathrm{mg} /$ day } \\
\hline & male & female \\
\hline \multicolumn{3}{|l|}{ Infants $^{\mathrm{a}}$} \\
\hline 0 to under 4 months & \multicolumn{2}{|c|}{0.1} \\
\hline 4 to under 12 months & \multicolumn{2}{|c|}{0.3} \\
\hline \multicolumn{3}{|l|}{ Children and adolescents } \\
\hline 1 to under 4 years & \multicolumn{2}{|c|}{0.6} \\
\hline 4 to under 7 years & \multicolumn{2}{|c|}{0.7} \\
\hline 7 to under 10 years & \multicolumn{2}{|c|}{1.0} \\
\hline 10 to under 13 years & \multicolumn{2}{|c|}{1.2} \\
\hline 13 to under 15 years & 1.5 & 1.4 \\
\hline 15 to under 19 years & 1.6 & 1.4 \\
\hline \multicolumn{3}{|l|}{ Adults } \\
\hline 19 to under 25 years & 1.6 & 1.4 \\
\hline 25 to under 51 years & 1.6 & 1.4 \\
\hline 51 to under 65 years & 1.6 & 1.4 \\
\hline 65 years and older & 1.6 & 1.4 \\
\hline \multicolumn{3}{|l|}{ Pregnant women } \\
\hline 1st trimester & & 1.5 \\
\hline 2nd and 3rd trimesters & & 1.8 \\
\hline Lactating women & & 1.6 \\
\hline
\end{tabular}

${ }^{\text {a }}$ Estimated values.

or $1.55 \mathrm{~g} / \mathrm{kg}$ body weight reported in some of these intervention trials $[37,53-55]$. According to the combined analysis of 5 balance studies [37, 49,53-55], the average vitamin $\mathrm{B}_{6}$ requirement to ensure a plasma PLP concentration of $\geq 30 \mathrm{nmol} / \mathrm{L}$ is $1.2 \mathrm{mg} /$ day, considering the higher bioavailability of synthetic PN [37]. Assuming a coefficient of variation of $10 \%$ (addition of $20 \%$ ), the RI for women aged 19 to under 65 years is $1.4 \mathrm{mg}$ /day (Table 1).

As there are no convincing balance studies in men, their requirement was extrapolated from the derived requirement in women. Assuming that vitamin $B_{6}$ requirement depends on the metabolically active body mass [28], and taking into account an allometric exponent, the $\mathrm{AR}$ in men is $1.4 \mathrm{mg} /$ day. Allometric scaling is based on the association between body mass and metabolism. According to Kleiber's law, the metabolism scaled with a potency of 0.75 of body mass $[56,57]$. Due to the dependence of $\mathrm{B}$ vitamins on the metabolic body mass, an allometric exponent of 0.75 is included in the calculation. Considering a coefficient of variation of $10 \%$ (addition of $20 \%$ ), the RI for men aged 19 to under 65 years is $1.6 \mathrm{mg} /$ day (Table 2). 
Table 2. Derivation of the average requirement and recommended intake values for vitamin $B_{6}$ for men $\geq 19$ years of age considering differences in average body weight and an allometric exponent

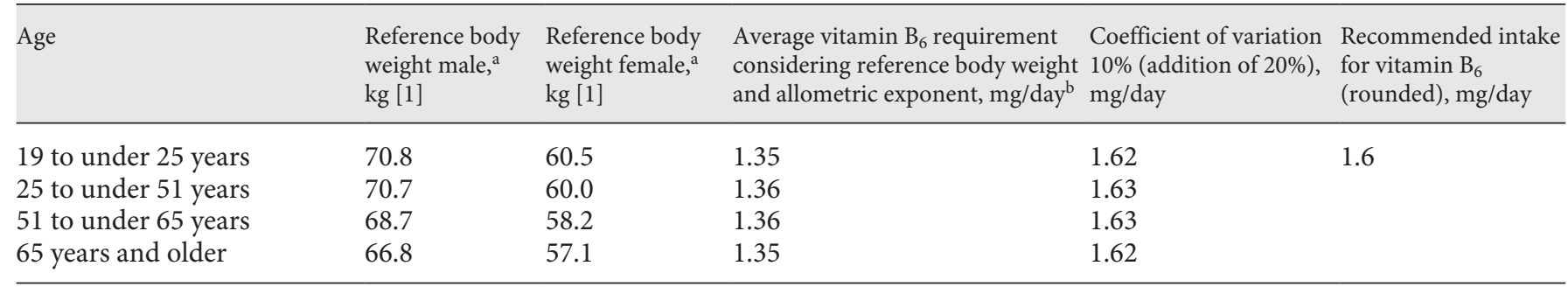

a Reference values for body weight are calculated from the median body height determined in the German Health Interview and Examination Survey for Adults (DEGS1) corresponding to a BMI of $22 \mathrm{~kg} / \mathrm{m}^{2}$ [1]. Based on data of DEGS1, the median body heights were $179.4,179.2,176.7$, and $174.2 \mathrm{~cm}$ for male subjects in the age groups 18-29, 30-39, 50-59, and 60-69 years, respectively [97]. For female subjects, the median body heights were $165.8,165.1,162.6$, and $161.1 \mathrm{~cm}$ in the respective age groups [97]. These median values were used for the appropriate age groups mentioned in this table, albeit the age classification is not entirely homogeneous. ${ }^{\mathrm{b}}$ Calculated from: average requirement $_{\text {women }}[\mathrm{mg} /$ day $] \times\left(\text { reference body weight }_{\text {men }}[\mathrm{kg}] / \text { reference body weight }_{\text {women }}[\mathrm{kg}]\right)^{\text {allometric exponent }}[28]$; average requirement $_{\text {women: }} 1.2 \mathrm{mg} /$ day; allometric exponent: 0.75 .

Adults above 65 Years of Age

Several cross-sectional studies showed an inverse association between age and PLP concentration $[38,51,58-$ $61]$; others, however, did not [32, 62, 63]. In a long-term study including 360 subjects $\geq 60$ years of age, no decrease of the PLP concentration with advancing age was observed [52]. Possible causes discussed for lower PLP concentrations in elderly people comprise lower vitamin $\mathrm{B}_{6}$ intake, reduced albumin synthesis, inflammation, and increased alkaline phosphatase activity $[16,36,62]$. However, age-related changes of vitamin $\mathrm{B}_{6}$ bioavailability or metabolism have not been proven so far $[36,62]$. In a study including 12 subjects aged $>60$ years, the vitamin $\mathrm{B}_{6}$ intake level was estimated that was required at different protein intakes to regain the baseline plasma PLP concentration after a low-vitamin $\mathrm{B}_{6}$ diet [50]. In 2 women and 1 man who had a daily protein intake of $0.8 \mathrm{~g} / \mathrm{kg}$ body weight, this required a vitamin $\mathrm{B}_{6}$ intake of $1.33 \mathrm{mg} /$ day (women) and $1.36 \mathrm{mg} /$ day (men), respectively. Due to the small sample size and the fact that baseline PLP concentrations exceeded $30 \mathrm{nmol} / \mathrm{L}$ [50], the RI for adults above 65 years of age is $1.4 \mathrm{mg} /$ day for women and $1.6 \mathrm{mg} /$ day for men (Table 1) and thus corresponds to the reference values of younger adults.

\section{Children and Adolescents}

No data from balance studies are available regarding the vitamin $B_{6}$ requirement for children and adolescents. Therefore, the reference values for children and adolescents are based on the values compiled for adults and take into account differences in body weight, an allometric ex- ponent, growth factors to consider the requirements for growth, and a coefficient of variation of $10 \%$ (addition of $20 \%$ ) (Table 3 ). Growth factors at the different age groups were calculated from the protein requirement for growth in relation to the maintenance requirement according to the World Health Organization (WHO) [14, 64]. When using the age groups and reference body weights the DA-CH reference values are based upon [1], the AR values range between 0.5 and $1.5 \mathrm{mg} /$ day. The resulting RI values for vitamin $\mathrm{B}_{6}$ range from $0.6 \mathrm{mg} /$ day (for 1 to under 4-year-olds) to $1.4 \mathrm{mg} /$ day for female adolescents and 1.6 $\mathrm{mg} /$ day for male adolescents (15 to under 19-year-olds) (Tables 1, 3). We want to point out that the calculated values for adolescents aged 15 to under 19 years are higher than those for adults (Table 3). However, as no evidence of a higher vitamin $\mathrm{B}_{6}$ requirement for adolescents exists, the RI values for female and male adolescents aged 15 to under 19 years are assumed to be the same as for adults (Table 3 ).

\section{Infants}

The reference values for the intake of vitamin $B_{6}$ for infants aged 0 to under 4 months were derived based on the vitamin $\mathrm{B}_{6}$ content of breast milk, which is considered to be the optimal diet for infants $[65,66]$. The reference values for infants are therefore estimated values.

The average vitamin $\mathrm{B}_{6}$ content from 2 studies of mature milk from lactating women not supplementing vita$\min B_{6}$ is $0.145 \mathrm{mg} / \mathrm{L}[67,68]$. Assuming an average breast milk intake of $750 \mathrm{~mL} /$ day [69], vitamin $\mathrm{B}_{6}$ intake in an exclusively breastfed infant is approximately $0.109 \mathrm{mg}$ vi- 
Table 3. Derivation of the average requirement and recommended intake values for vitamin $\mathrm{B}_{6}$ for children and adolescents considering differences in average body weight, an allometric exponent, and growth factors

\begin{tabular}{|c|c|c|c|c|c|c|}
\hline Age & Sex & $\begin{array}{l}\text { Reference } \\
\text { body weight, }{ }^{a} \\
\operatorname{kg}[1]\end{array}$ & $\begin{array}{l}\text { Growth } \\
\text { factor }^{b}[1]\end{array}$ & $\begin{array}{l}\text { Average vitamin } \mathrm{B}_{6} \\
\text { requirement considering } \\
\text { reference body weight, } \\
\text { allometric exponent, and } \\
\text { growth factor, }{ }^{\mathrm{c}} \mathrm{mg} / \mathrm{day}\end{array}$ & $\begin{array}{l}\text { Coefficient of } \\
\text { variation } 10 \% \\
\text { (addition of } 20 \% \text { ), } \\
\text { mg/day }\end{array}$ & $\begin{array}{l}\text { Recommended } \\
\text { intake for vitamin } \\
\mathrm{B}_{6} \text { (rounded), } \\
\mathrm{mg} / \text { day }\end{array}$ \\
\hline \multirow{2}{*}{1 to under 4 years } & Male & 13.9 & 0.25 & 0.52 & 0.62 & \multirow[b]{2}{*}{0.6} \\
\hline & Female & 13.2 & 0.25 & 0.48 & 0.58 & \\
\hline 4 to under 7 years & Female & 20.1 & 0.06 & 0.56 & 0.67 & 0.7 \\
\hline \multirow[t]{2}{*}{7 to under 10 years } & Male & 29.3 & 0.13 & 0.82 & 0.98 & \multirow{2}{*}{1.0} \\
\hline & Female & 28.7 & 0.13 & 0.78 & 0.94 & \\
\hline \multirow[t]{2}{*}{10 to under 13 years } & Male & 41.0 & 0.13 & 1.05 & 1.26 & \multirow{2}{*}{1.2} \\
\hline & Female & 42.1 & 0.11 & 1.02 & 1.23 & \\
\hline 15 to under 19 years & Female & 59.5 & 0.02 & 1.22 & 1.46 & $1.4^{\mathrm{d}}$ \\
\hline
\end{tabular}

${ }^{a}$ Reference values for body weight correspond to the median body weight determined in the German Health Interview and Examination Survey for Children and Adolescents in Germany (KiGGS; 2003-2006) [98]. In each case, the values reflect the midpoint of the respective age range. ${ }^{\mathrm{b}}$ Growth factors at the different ages were calculated as the proportional increase in protein requirement for growth relative to the maintenance requirement according to the WHO $[14,64] .{ }^{\mathrm{c}}$ Calculated from: average requirement ${ }_{\text {adults }}[\mathrm{mg} / \mathrm{day}] \times(\mathrm{reference} \mathrm{body}$ weight $_{\text {children/adolescents }}[\mathrm{kg}] /$ reference body weight $\left.{ }_{\text {adults }}[\mathrm{kg}]\right)^{\text {allometric exponent }} \times\left(1+\right.$ growth factor $\left._{\text {children/adolescents }}\right)$ [28]; average requirement ${ }_{\text {adults: }}$ male $1.4 \mathrm{mg} /$ day, female $1.2 \mathrm{mg}$ /day; reference body weight ${ }_{\text {adults }}$ (age group 25 to under 51 years): men $70.7 \mathrm{~kg}$, women $60.0 \mathrm{~kg}$ [1]; allometric exponent: $0.75 .{ }^{\mathrm{d}}$ For adolescents aged 15 to under 19 years, the reference value is assumed to be the same as for adults (see Table 1), as there is no evidence of a higher requirement.

tamin $\mathrm{B}_{6} /$ day. This intake is sufficient to ensure a PLP concentration of $\geq 30 \mathrm{nmol} / \mathrm{L}$ [68]. Therefore, the estimated value for adequate vitamin $B_{6}$ intake is $0.1 \mathrm{mg} / \mathrm{day}$ for infants aged 0 to under 4 months.

For infants aged 4 to under 12 months, data on the average vitamin $\mathrm{B}_{6}$ requirement are lacking. Thus, in line with the approach of the European Food Safety Authority (EFSA) [28], the vitamin $B_{6}$ reference value for infants of this age group is derived by averaging the results of the extrapolation from the estimated value for infants under 4 months of age and of the extrapolation from the AR for adults. Based on the estimated value for infants under 4 months of age $(0.1 \mathrm{mg} /$ day), considering differences in body weight [1] and the allometric exponent, the vitamin $\mathrm{B}_{6}$ intake is $0.14 \mathrm{mg} /$ day. However, based on the average vitamin $\mathrm{B}_{6}$ requirement for adults $(1.2 \mathrm{mg} /$ day for women and $1.4 \mathrm{mg}$ /day for men), considering differences in body weight, the allometric exponent, and the growth factor [1], the vitamin $B_{6}$ intake is $0.45 \mathrm{mg} /$ day for female infants and $0.49 \mathrm{mg} /$ day for male infants. By calculating the arithmetic mean, an estimated value for an adequate vitamin $\mathrm{B}_{6}$ intake of $0.3 \mathrm{mg} /$ day is derived (Table 4).

\section{Pregnancy}

Plasma PLP concentration decreases during pregnancy; especially in the third trimester, concentrations $<20$ $\mathrm{nmol} / \mathrm{L}$ were observed [70-72]. Possible reasons are haemodilution, enhanced PLP transfer to the foetus, increased alkaline phosphatase activity, and a higher requirement due to tissue growth [72, 73]. In line with the EFSA [28], the requirement during pregnancy is derived on the basis of body weight gain and average tissue content of vitamin $\mathrm{B}_{6}$. Based on weight gain during pregnancy $(16.7 \mathrm{~g} /$ day in the first, $60.6 \mathrm{~g} /$ day in the second, and $54.2 \mathrm{~g} /$ day in the third trimester [1]), a vitamin $\mathrm{B}_{6}$ requirement of $15 \mathrm{nmol} / \mathrm{g}$ tissue growth $(3.7 \mathrm{mg} / \mathrm{kg}$ ) [30] and an average bioavailability of $75 \%$, the AR is $1.3 \mathrm{mg} /$ day in the first trimester and $1.5 \mathrm{mg} /$ day in the second and third trimesters. After taking a coefficient of variation of $10 \%$ (addition of 20\%) into account, the recommended vitamin 
Table 4. Derivation of the estimated value for the intake of vitamin $\mathrm{B}_{6}$ for infants aged 4 to under 12 months

\begin{tabular}{|c|c|c|c|c|c|c|}
\hline Age & Sex & $\begin{array}{l}\text { Reference } \\
\text { body weight, }{ }^{\text {a }} \\
\text { kg [1] }\end{array}$ & $\begin{array}{l}\text { Derivation based on the } \\
\text { estimated value for infants } \\
\text { under } 4 \text { months of age: vitamin } \\
\mathrm{B}_{6} \text { intake considering reference } \\
\text { body weight and allometric } \\
\text { exponent, }{ }^{\text {b }} \mathrm{mg} / \text { day }\end{array}$ & $\begin{array}{l}\text { Derivation based on the average } \\
\text { vitamin } \mathrm{B}_{6} \text { requirement for } \\
\text { adults: vitamin } \mathrm{B}_{6} \text { intake } \\
\text { considering reference body } \\
\text { weight, allometric exponent, and } \\
\text { growth factor, }{ }^{\mathrm{c}} \mathrm{mg} / \text { day }\end{array}$ & $\begin{array}{l}\text { Averaged } \\
\text { vitamin } \mathrm{B}_{6} \\
\text { intake } \\
\text { considering both } \\
\text { extrapolation } \\
\text { paths, mg/day }\end{array}$ & $\begin{array}{l}\text { Estimated } \\
\text { value for the } \\
\text { vitamin } \mathrm{B}_{6} \\
\text { intake } \\
\text { (rounded), } \\
\mathrm{mg} / \text { day }\end{array}$ \\
\hline $\begin{array}{l}4 \text { to under } 12 \\
\text { months }\end{array}$ & Male & 8.6 & 0.14 & 0.49 & 0.31 & 0.3 \\
\hline
\end{tabular}

${ }^{a}$ Reference values for body weight correspond to the median body weight of the WHO child growth standards [99] for the age of 8 months. ${ }^{\mathrm{b}}$ Calculated from: estimated value ${ }_{0-4}$ months $[\mathrm{mg} /$ day $] \times\left(\right.$ reference body weight $_{4-12 \text { months }}[\mathrm{kg}] /$ reference body weight $_{0-4}$ months $[\mathrm{kg}])^{\text {allometric exponent }}$ according to [28]; estimated value ${ }_{0-4}$ months: $0.1 \mathrm{mg} /$ day (see Table 1 ); reference body weight ${ }_{0-4}$ months: $\mathrm{male} 5.6 \mathrm{~kg}$, female $5.1 \mathrm{~kg}$ [1]; allometric exponent: $0.75 .{ }^{c}$ Calculated from: average vitamin $\mathrm{B}_{6}$ requirement ${ }_{\text {adults }}$ [mg/day] $\times($ reference body weight $_{4-12 \text { months }}[\mathrm{kg}] /$ reference body weight $\left.{ }_{\text {adults }}[\mathrm{kg}]\right)^{\text {allometric exponent }} \times\left(1+\right.$ growth factor $_{0-4}$ months $)$ according to [28]; average vitamin $\mathrm{B}_{6}$ requirement $_{\text {adults: }}$ male $1.4 \mathrm{mg} /$ day, female $1.2 \mathrm{mg} /$ day; reference body weight ${ }_{\text {adults }}$ (age group 25 to under 51 years): male $70.7 \mathrm{~kg}$, female $60.0 \mathrm{~kg}$ [1]; allometric exponent: 0.75; growth factor $4-12$ months: 0.7 [1].

$\mathrm{B}_{6}$ intake for pregnant women is $1.5 \mathrm{mg} /$ day in the first trimester and $1.8 \mathrm{mg} /$ day in the second and third trimesters.

\section{Lactation}

Vitamin $\mathrm{B}_{6}$ concentration of breast milk is influenced by the mother's diet [67]. Based on a vitamin $B_{6}$ secretion with breast milk of $0.1 \mathrm{mg} /$ day (see the section Infants), an average bioavailability of $75 \%$ and an average breast milk intake of $750 \mathrm{~mL} /$ day of an exclusively breastfed infant, the AR in lactating women is $1.3 \mathrm{mg} /$ day. Considering a coefficient of variation of $10 \%$ (addition of $20 \%$ ), the recommended vitamin $B_{6}$ intake is $1.6 \mathrm{mg} /$ day.

\section{Preventive Aspects}

In the following, the available data on health-related aspects of vitamin $B_{6}$ are outlined without an evidence judgement. As most studies do not investigate vitamin $\mathrm{B}_{6}$ alone but in combination with other B vitamins, it is sometimes not possible to evaluate the unique role of the different $\mathrm{B}$ vitamins.

Several epidemiological long-term studies repeatedly demonstrated inverse associations between vitamin $\mathrm{B}_{6}$ status or vitamin $B_{6}$ intake and risk of depression [74], cardiovascular diseases [75], and cognitive impairment $[76,77]$. Furthermore, an inverse association between vitamin $\mathrm{B}_{6}$ status and inflammation has been described [41, $43,78]$. Meta-analyses of epidemiological studies indicate negative associations for both dietary vitamin $\mathrm{B}_{6}$ intake and PLP concentration with the general risk of cancer and specifically the risk of cancers of the gastrointestinal tract such as the colorectum $[79,80]$, oesophagus, stomach, and pancreas [80]. Another meta-analysis indicates a negative association between the PLP concentration and the risk of breast cancer in postmenopausal women [81]. However, an association between vitamin $\mathrm{B}_{6}$ intake and risk of breast cancer could not be proven [81].

So far, most intervention studies could not confirm preventive effects of vitamin $\mathrm{B}_{6}$ regarding risk of cancer, depression, cardiovascular diseases, impairment of cognitive functions in older age or Alzheimer's disease, or an effect on bone remodelling [80, 82-89]. Based on available data, a vitamin $\mathrm{B}_{6}$ intake exceeding the reference values is not clearly associated with preventive effects on health in the general population.

\section{Discussion and Conclusion}

Within the present revision of the $\mathrm{D}-\mathrm{A}-\mathrm{CH}$ reference values for the intake of vitamin $B_{6}$, the method of derivation has been changed: it is now based on balance studies using plasma PLP concentration as a biomarker to determine the AR. Reliable data on the vitamin $\mathrm{B}_{6}$ intake levels that are sufficient to achieve the desirable plasma PLP concentration of $30 \mathrm{nmol} / \mathrm{L}$ are available for women, but not for children, adolescents, and men. Therefore, the reference values for children and adolescents were derived from the data for women considering differences in body weight and increased requirements in children and ado- 
lescents due to growth. Likewise, the reference values for men were derived based on the AR of women with consideration of differences in body weight. Due to the changed derivation, the reference values for some age groups are slightly higher than before. For pregnancy and lactation, the reference values are somewhat lower. However, higher intake levels for pregnant women compared to non-pregnant women are now recommended already in the first trimester, whereas previously higher intake levels were recommended from the beginning of the second trimester.

The derivation and magnitude of the revised reference values show similarities as well as differences to the derivation and magnitude of reference values set by the EFSA [28], Institute of Medicine (IOM) [90], and WHO [91]. For infants, the $\mathrm{D}-\mathrm{A}-\mathrm{CH}$ reference values for vitamin $\mathrm{B}_{6}$ are in line with the reference values set by EFSA, IOM, and $\mathrm{WHO}$, whereas for other age categories as well as for pregnant and lactating women, differences can be noted.

Similarities regarding the derivation include (1) the absence of connecting the vitamin $\mathrm{B}_{6}$ requirements to the protein intake levels, (2) the use of the circulating PLP concentration as a biomarker for vitamin $\mathrm{B}_{6}$ status, (3) the extrapolation of the ARs for children, adolescents, and pregnant/lactating women from the ARs of adults, (4) the vitamin $\mathrm{B}_{6}$ content in human milk as a basis for deriving reference values for infants, (5) the higher AR for pregnancy and lactation due to foetus requirements and milk secretion, respectively, and (6) the nature of the reference values, that is, adequate intake and estimated values for infants and RIs for adolescents and adults.

The differences include, for instance, (1) cut-off values for defining adequate PLP concentrations, (2) age categories, reference body weights, and growth factors, (3) age at which sex-specific reference values were applied, (4) requirements of older adults, and (5) reference values depending on trimester. More precisely, IOM [90] and WHO [91] use a PLP concentration of $\geq 20 \mathrm{nmol} / \mathrm{L}$ to define an adequate vitamin $\mathrm{B}_{6}$ status and also consider studies analyzing other vitamin $B_{6}$ biomarkers, such as activation coefficients of erythrocyte aspartate aminotransferase and erythrocyte alanine aminotransferase as well as homocysteine concentration and the renal excretion of tryptophan metabolites following a tryptophan loading test to derive ARs for adults, respectively. In contrast, EFSA bases the derivation of ARs on the achievement of a PLP concentration of $\geq 30 \mathrm{nmol} / \mathrm{L}$ [28] similar to the here presented derivation. With respect to the age groups, the D-A-CH reference values for children and adolescents are stratified into 7 age groups, whereas IOM [90] and WHO [91] use only 4 and EFSA [28] applies 5 age groups. This and the fact that different population studies were quoted as source of the reference body weights and growth factors explain why the age at which sex-specific reference values were set differs among the authorities. With reference to the above-mentioned study by RibayaMercado et al. [50], IOM [90] and WHO [91] assume that older subjects require a higher vitamin $\mathrm{B}_{6}$ intake to maintain a sufficient vitamin $\mathrm{B}_{6}$ state compared to young adults and thus set age-specific reference values for adults. EFSA [28] abstains from setting age-specific reference values in adulthood but takes the results from RibayaMercado et al. [50] into account by applying an AR of 1.3 $\mathrm{mg} /$ day for women and, after extrapolation, $1.5 \mathrm{mg} /$ day for men. In contrast, D-A-CH nutrition societies conclude that the evidence is insufficient to set a higher AR and in consequence RI for older adults. In terms of pregnancy, the here presented $\mathrm{D}-\mathrm{A}-\mathrm{CH}$ reference values for pregnant women are the only ones that imply a trimesterspecific vitamin $\mathrm{B}_{6}$ intake, although EFSA [28], IOM [90], and WHO [91] acknowledge that the lower vitamin $\mathrm{B}_{6}$ state is particularly evident in late gestation. In contrast to EFSA [28], IOM [90], and WHO [91], the D-A-CH reference values are based on trimester-specific weight gain during pregnancy taking into account that vitamin $\mathrm{B}_{6}$ requirements rely on tissue growth.

According to representative data from the German National Nutrition Survey II, the median vitamin $\mathrm{B}_{6}$ intake is $1.2 \mathrm{mg} /$ day in women and $1.6 \mathrm{mg} /$ day in men $[92,93]$. This means that the recommended vitamin $\mathrm{B}_{6}$ intake of $1.4 \mathrm{mg} /$ day for women and $1.6 \mathrm{mg} /$ day for men is not achieved by parts of the general adult population in Germany. Using the PRIs set by EFSA [28], that is, $1.6 \mathrm{mg}$ /day for women and $1.7 \mathrm{mg} /$ day for men, the situation appears even more critical, particularly for female subjects. However, irrespectively of the applied reference value, a vitamin $B_{6}$ intake below the RI does not necessarily represent a state of vitamin $B_{6}$ deficiency; rather it indicates a higher risk of suboptimal intake. The aim of reference values is the adequate nutrient supply of the healthy individuals in a population. The RI meets the requirements of $\sim 98 \%$ of the population. Thus, the RI exceeds the actual requirements of most people. Therefore, the RI is not suitable to distinguish between an adequate and inadequate nutrient intake on individual level or to diagnose a state of nutrient deficiency. For the examination of the probability that the usual intake of an individual is inadequate or to estimate the prevalence of inadequate intake in groups, the AR can be used [94, 95]. Referring to the AR, the above-mentioned median vitamin $B_{6}$ intake levels found in the Ger- 
man National Nutrition Survey II are in line with the AR for women and exceeded the AR for men. In light of this and the fact that the nutrient data base used to calculate the vitamin $B_{6}$ intake levels in the German National Nutrition Survey II considered predominantly non-fortified foods, vitamin $\mathrm{B}_{6}$ is apparently no critical nutrient for the general population. However, the diagnosis of a deficiency should base on a comprehensive individual assessment including the measurement of recognized biomarkers, such as plasma PLP concentration for vitamin $\mathrm{B}_{6}$.

Several protein-rich foods are good vitamin $B_{6}$ sources [16]. High levels of vitamin $B_{6}$ can be found in fish, such as sardines (cooked: $0.92 \mathrm{mg} / 100 \mathrm{~g}$ ) and mackerels (cooked: $0.59 \mathrm{mg} / 100 \mathrm{~g}$ ), as well as meat products, such as beef liver (cooked: $0.91 \mathrm{mg} / 100 \mathrm{~g}$ ) [96]. In addition, cereals (e.g., whole-wheat flour: $0.46 \mathrm{mg} / 100 \mathrm{~g}$ ), nuts (e.g., hazelnut: $0.66 \mathrm{mg} / 100 \mathrm{~g}$ and walnuts: $0.60 \mathrm{mg} / 100 \mathrm{~g}$ ), dried fruits (banana: $0.93 \mathrm{mg} / 100 \mathrm{~g}$ and mango: $0.51 \mathrm{mg} / 100 \mathrm{~g}$ ), and some vegetables (e.g., raw red pepper: $0.45 \mathrm{mg} / 100 \mathrm{~g}$ ) contain relatively high amounts of vitamin $\mathrm{B}_{6}$ [96]. However, as pointed out previously, plant-based foods show sometimes high amounts of PNG [24]. For instance, high levels of PNG were noticed in frozen cauliflower/broccoli, cooked soy beans, raisins, fresh orange juice, and carrots with around two-thirds of the total vitamin $\mathrm{B}_{6}$ content [24]. In contrast, the PNG proportion in walnuts, wholewheat flour, bananas, and raw cauliflower is expected to be below 20\% [24]. In a mixed diet, PNG usually accounts for approximately $15 \%$ of the total vitamin $\mathrm{B}_{6}$ amount [26]. Thus, a mixed diet can provide adequate amounts of vitamin $\mathrm{B}_{6}$ under the assumption of a bioavailability of $75 \%$. The bioavailability was taken into account by the
D-A-CH nutrition societies when setting the reference values. To achieve adequate vitamin $\mathrm{B}_{6}$ supply, the daily intake of whole-grain products, vegetables, and fruits including a portion of nuts is recommended. Intake of fish once to twice a week and a low amount of meat can also contribute to cover the vitamin $\mathrm{B}_{6}$ requirement.

\section{Acknowledgement}

The authors thank Professor Dr. Sabine Ellinger, Birte Peterson-Sperlich, and Prof. Dr. Bernhard Watzl for their valuable suggestions and contribution to the preparation of the revised reference values for vitamin $\mathrm{B}_{6}$ intake.

\section{Conflict of Interest Statement}

The authors have no conflicts of interest to declare.

\section{Funding Sources}

Dr. Alexandra Jungert received an honorarium from the German Nutrition Society (DGE) for developing the first draft of the dietary reference values for vitamin $\mathrm{B}_{6}$ intake.

\section{Author Contributions}

A.J. conducted the literature research and drafted the manuscript. J.L, K.-H.W., and M.R. revised the draft critically. All authors contributed to the conception of the manuscript and interpreted the data. All authors read and approved the final manuscript.

\section{References}

1 Deutsche Gesellschaft für Ernährung, Österreichische Gesellschaft für Ernährung, Schweizerische Gesellschaft für Ernährung (eds): Referenzwerte für die Nährstoffzufuhr, 2. Auflage, 5. aktualisierte Ausgabe. Bonn, 2019, 4. Ergänzungslieferung.

2 Bechthold A, Albrecht V, Leschik-Bonnet E, Heseker H. Evaluation of vitamin supplies in Germany. Data on vitamin intake. 2012 [cited 2018 Jul 18]. Available from: https://www. dge.de/fileadmin/public/doc/ws/statement/ 130515-DGE-statement-vitamin-supply.pdf.

3 German Nutrition Society. New reference values for vitamin D. Ann Nutr Metab. 2012; 60(4):241-6.

4 German Nutrition Society. New reference values for calcium. Ann Nutr Metab. 2013; 63(3):186-92.
5 Krawinkel MB, Strohm D, Weissenborn A, Watzl B, Eichholzer M, Bärlocher K, et al. Revised $\mathrm{D}-\mathrm{A}-\mathrm{CH}$ intake recommendations for folate: how much is needed? Eur J Clin Nutr. 2014;68(6):719-23.

6 Kipp AP, Strohm D, Brigelius-Flohé R, Schomburg L, Bechthold A, Leschik-Bonnet $\mathrm{E}$, et al. Revised reference values for selenium intake. J Trace Elem Med Biol. 2015;32:195-9.

7 German Nutrition Society. New reference values for energy intake. Ann Nutr Metab. 2015;66(4):219-23.

8 German Nutrition Society. New reference values for vitamin C intake. Ann Nutr Metab. 2015;67(1):13-20.

9 Strohm D, Bechthold A, Isik N, Leschik-Bonnet E, Heseker $\mathrm{H}$. Revised reference values for the intake of thiamin (vitamin B1), riboflavin (vitamin B2), and niacin. NFS J. 2016;3:20-4.
10 Strohm D, Ellinger S, Leschik-Bonnet E, Maretzke F, Heseker H. Revised reference values for potassium intake. Ann Nutr Metab. 2017; 71(1-2):118-24.

11 Strohm D, Bechthold A, Ellinger S, LeschikBonnet E, Stehle P, Heseker H, et al. Revised reference values for the intake of sodium and chloride. Ann Nutr Metab. 2018;72(1):12-7.

12 Ströhle A, Richter M, González-Gross M, Neuhäuser-Berthold $M$, Wagner K-H, Leschik-Bonnet $\mathrm{E}$, et al. The revised D-A-CHreference values for the intake of vitamin B12: prevention of deficiency and beyond. Mol Nutr Food Res. 2019;63(6):1801178.

13 Richter M, Baerlocher K, Bauer JM, Elmadfa I, Heseker H, Leschik-Bonnet E, et al. Revised reference values for the intake of protein. Ann Nutr Metab. 2019;74(3):242-50. 
14 Deutsche Gesellschaft für Ernährung. Referenzwerte für die Nährstoffzufuhr. Umschau Verlag; 2000.

15 Phillips MM. Liquid chromatography with isotope-dilution mass spectrometry for determination of water-soluble vitamins in foods. Anal Bioanal Chem. 2015;407(11):2965-74.

16 Ueland P, Ulvik A, Rios-Avila L, Midttun $\varnothing$, Gregory J. Direct and functional biomarkers of vitamin B6 status. Annu Rev Nutr. 2015;35: 33-70.

17 Percudani R, Peracchi A. The B6 database: a tool for the description and classification of vitamin B6-dependent enzymatic activities and of the corresponding protein families. BMC Bioinformatics. 2009;10:273.

18 Shibata K, Mushiage M, Kondo T, Hayakawa $T$, Tsuge $H$. Effects of vitamin B6 deficiency on the conversion ratio of tryptophan to niacin. Biosci Biotechnol Biochem. 1995;59(11): 2060-3.

19 Bourquin F, Capitani G, Grütter MG. PLPdependent enzymes as entry and exit gates of sphingolipid metabolism. Protein Sci. 2011; 20(9):1492-508.

20 Shoolingin-Jordan PM, Al-Daihan S, Alexeev D, Baxter RL, Bottomley SS, Kahari ID, et al. 5-aminolevulinic acid synthase: mechanism, mutations, and medicine. Biochim Biophys Acta. 2003;1647(1-2):361-6.

21 Clayton PT. B6-responsive disorders: a model of vitamin dependency. J Inherit Metab Dis. 2006;29(2-3):317-26.

22 Porter K, Hoey L, Hughes CF, Ward M, McNulty $\mathrm{H}$. Causes, consequences and public health implications of low B-vitamin status in ageing. Nutrients. 2016;8(11):E725.

23 Schroeder HA. Losses of vitamins and trace minerals resulting from processing and preservation of foods. Am J Clin Nutr. 1971;24(5): $562-73$.

24 Reynolds RD. Bioavailability of vitamin B-6 from plant foods. Am J Clin Nutr. 1988;49(4): $717-7$.

25 Nakano H, McMahon L, Gregory J. Pyridoxine-5' -beta-glucoside exhibits incomplete bioavailability as a source of vitamin B-6 and partially inhibits the utilization of co-ingested pyridoxine in humans. J Nutr. 1997; 127(8):1508-13.

26 Gregory JF, Trumbo PR, Bailey LB, Toth JP, Baumgartner TG, Cerda JJ. Bioavailability of pyridoxine-5'-beta-d-glucoside determined in humans by stable-isotopic methods. J Nutr. 1991;121(2):177-86.

27 Tarr JB, Tamura T, Stokstad EL. Availability of vitamin B6 and pantothenate in an average American diet in man. Am J Clin Nutr. 1981; 34(7):1328-37.

28 EFSA (European Food Safety Authority). Dietary reference values for vitamin B6: EFSA panel on dietetic products, nutrition, and allergies (NDA). EFSA J. 2016;14:4485.

29 Coburn SP, Lewis DL, Fink WJ, Mahuren JD, Schaltenbrand WE, Costill DL. Human vitamin B-6 pools estimated through muscle biopsies. Am J Clin Nutr. 1988;48(2):291-4.
30 Coburn SP. Location and turnover of vitamin B6 pools and vitamin B6 requirements of humans. Ann N Y Acad Sci. 1990;585:76-85.

31 Coburn SP, Ziegler PJ, Costill DL, Mahuren JD, Fink WJ, Schaltenbrand WE, et al. Response of vitamin B-6 content of muscle to changes in vitamin B-6 intake in men. Am J Clin Nutr. 1991;53(6):1436-42.

32 Albersen M, Bosma M, Luykx JJ, Jans JJ, Bakker SC, Strengman E, et al. Vitamin B-6 vitamers in human plasma and cerebrospinal fluid. Am J Clin Nutr. 2014;100(2):587-92.

33 Lumeng L, Brashear RE, Li TK. Pyridoxal 5 -phosphate in plasma: source, proteinbinding, and cellular transport. J Lab Clin Med. 1974;84(3):334-43.

34 Lui A, Lumeng L, Aronoff GR, Li TK. Relationship between body store of vitamin B6 and plasma pyridoxal-P clearance: metabolic balance studies in humans. J Lab Clin Med. 1985;106(5):491-7.

35 Johansson S, Lindstedt S, Register U, Wadström L. Studies on the metabolism of labeled pyridoxine in man. Am J Clin Nutr. 1966; 18(3):185-96.

36 Kant AK, Moser-Veillon PB, Reynolds RD. Effect of age on changes in plasma, erythrocyte, and urinary B6 vitamers after an oral vitamin B6 load. Am J Clin Nutr. 1988;48(5):1284-90.

37 Hansen CM, Shultz TD, Kwak H-K, Memon HS, Leklem JE. Assessment of vitamin B-6 status in young women consuming a controlled diet containing four levels of vitamin B-6 provides an estimated average requirement and recommended dietary allowance. J Nutr. 2001;131(6):1777-86.

38 Morris M, Picciano M, Jacques P, Selhub J. Plasma pyridoxal $5^{\prime}$-phosphate in the US population: the National Health and Nutrition Examination Survey, 2003-2004. Am J Clin Nutr. 2008;87(5):1446-54.

39 Gregory JF, Park Y, Lamers Y, Bandyopadhyay N, Chi YY, Lee K, et al. Metabolomic analysis reveals extended metabolic consequences of marginal vitamin B-6 deficiency in healthy human subjects. PLoS One 2013;8(6):e63544.

40 da Silva VR, Rios-Avila L, Lamers Y, Ralat MA, Ø Midttun, Quinlivan EP, et al. Metabolite profile analysis reveals functional effects of 28-day vitamin B-6 restriction on one-carbon metabolism and tryptophan catabolic pathways in healthy men and women. J Nutr. 2013;143(11):1719-27.

41 Paul L, Ueland PM, Selhub J. Mechanistic perspective on the relationship between pyridoxal $5^{\prime}$-phosphate and inflammation. Nutr Rev. 2013;71(4):239-44.

42 Ulvik A, Midttun Ø, Pedersen ER, Eussen SJ, Nygård $\mathrm{O}$, Ueland PM. Evidence for increased catabolism of vitamin B-6 during systemic inflammation. Am J Clin Nutr. 2014, 100(1):250-5

43 Ueland PM, McCann A, Midttun $\varnothing$, Ulvik A. Inflammation, vitamin $\mathrm{B} 6$ and related pathways. Mol Aspects Med. 2017;53:10-27.

44 Cravo ML, Glória LM, Selhub J, Nadeau MR, Camilo ME, Resende MP, et al. Hyperhomo- cysteinemia in chronic alcoholism: correlation with folate, vitamin B-12, and vitamin B-6 status. Am J Clin Nutr. 1996;63(2):220-4.

45 Medici V, Peerson JM, Stabler SP, French SW, Gregory JF, Virata MC, et al. Impaired homocysteine transsulfuration is an indicator of alcoholic liver disease. J Hepatol. 2010;53(3):551-7.

46 Beulens JW, Sierksma A, Schaafsma G, Kok FJ, Struys EA, Jakobs C. Kinetics of homocysteine metabolism after moderate alcohol consumption. Alcohol Clin Exp Res. 2005;29(5): 739-45.

47 van der Gaag MS, Ubbink JB, Sillanaukee P, Nikkari S, Hendriks HF. Effect of consumption of red wine, spirits, and beer on serum homocysteine. Lancet. 2000;355(9214):1522.

48 Miller LT, Leklem JE, Shultz TD. The effect of dietary protein on the metabolism of vitamin B-6 in humans. J Nutr. 1985;115(12):166372.

49 Hansen CM, Leklem JE, Miller LT. Vitamin B-6 status of women with a constant intake of vitamin B-6 changes with three levels of dietary protein. J Nutr. 1996;126:1891-901.

50 Ribaya-Mercado JD, Russell RM, Sahyoun N, Morrow FD, Gershoff SN. Vitamin B-6 requirements of elderly men and women. J Nutr. 1991;121(7):1062-74.

51 Pannemans DL, van den Berg H, Westerterp KR. The influence of protein intake on vitamin B-6 metabolism differs in young and elderly humans. J Nutr. 1994;124(8):1207-14.

52 Jungert A, Neuhäuser-Berthold M. Determinants of vitamin B6 status in communitydwelling older adults: a longitudinal study over a period of 18 years. J Gerontol A Biol Sci Med Sci. 2020;75(2):374-9.

53 Kretsch MJ, Sauberlich HE, Skala JH, Johnson HL. Vitamin B-6 requirement and status assessment: young women fed a depletion diet followed by a plant- or animal-protein diet with graded amounts of vitamin B-6. Am J Clin Nutr. 1995;61(5):1091-101.

54 Huang YC, Chen W, Evans MA, Mitchell ME, Shultz TD. Vitamin B-6 requirement and status assessment of young women fed a highprotein diet with various levels of vitamin B-6. Am J Clin Nutr. 1998;67(2):208-20.

55 Hansen CM, Leklem JE, Miller LT. Changes in vitamin B-6 status indicators of women fed a constant protein diet with varying levels of vitamin B-6. Am J Clin Nutr. 1997;66(6): 1379-87.

56 Kleiber M. Body size and metabolic rate. Physiol Rev. 1947;27(4):511-41.

57 West GB, Brown JH, Enquist BJ. A general model for the origin of allometric scaling laws in biology. Science. 1997;276(5309):122-6.

58 Rose CS, György P, Butler M, Andres R, Norris $\mathrm{AH}$, Shock NW, et al. Age differences in vitamin B6 status of 617 men. Am J Clin Nutr. 1976;29(8):847-53.

59 Lee CM, Leklem JE. Differences in vitamin B6 status indicator responses between young and middle-aged women fed constant diets with two levels of vitamin B6. Am J Clin Nutr. 1985;42(2):226-34. 
60 Bates CJ, Pentieva KD, Prentice A. An appraisal of vitamin B6 status indices and associated confounders, in young people aged 4-18 years and in people aged 65 years and over, in two national British surveys. Public Health Nutr. 1999;2(4):529-35.

61 Gori AM, Sofi F, Corsi AM, Gazzini A, Sestini I, Lauretani F, et al. Predictors of vitamin B6 and folate concentrations in older persons: the InCHIANTI study. Clin Chem. 2006; 52(7):1318-24.

62 Ferroli CE, Trumbo PR. Bioavailability of vitamin B-6 in young and older men. Am J Clin Nutr. 1994;60(1):68-71.

63 Page JH, Ma J, Chiuve SE, Stampfer MJ, Selhub J, Manson JE, et al. Plasma vitamin B(6) and risk of myocardial infarction in women. Circulation. 2009;120(8):649-55.

64 WHO (World Health Organization). Protein and amino acid requirements in human nutrition. World Health Organ Tech Rep Ser. 2007;935(935):1.

65 Heiskanen K, Siimes MA, Perheentupa J, Salmenperä L. Risk of low vitamin B6 status in infants breast-fed exclusively beyond six months. J Pediatr Gastroenterol Nutr. 1996; 23(1):38-44.

66 Butte NF, Lopez-Alarcon MG, Garza C. Nutrient adequacy of exclusive breastfeeding for the term infant during the first six months of life, WHO (World Health Organization). 2002 [cited 2019 Feb 4]. Available from: https://apps. who.int/iris/bitstream/handle/10665/ 42519/9241562110.pdf?sequence $=1$.

67 West KD, Kirksey A. Influence of vitamin B6 intake on the content of the vitamin in human milk. Am J Clin Nutr. 1976;29(9):961-9.

68 Andon MB, Reynolds RD, Moser-Veillon PB, Howard MP. Dietary intake of total and glycosylated vitamin B-6 and the vitamin B-6 nutritional status of unsupplemented lactating women and their infants. Am J Clin Nutr. 1989;50(5):1050-8.

69 Neville MC, Keller R, Seacat J, Lutes V, Neifert $\mathrm{M}$, Casey C, et al. Studies in human lactation: milk volumes in lactating women during the onset of lactation and full lactation. Am J Clin Nutr. 1988;48(6):1375-86.

70 Dror DK, Allen LH. Interventions with vitamins B6, B12 and C in pregnancy. Paediatr Perinat Epidemiol. 2012;26(Suppl 1):55-74.

71 Shibata K, Tachiki A, Mukaeda K, Fukuwatari T, Sasaki S, Jinno Y. Changes in plasma pyridoxal $5^{\prime}$-phosphate concentration during pregnancy stages in Japanese women. J Nutr Sci Vitaminol. 2013;59(4):343-6.

72 Mujica-Coopman MF, Franco-Sena AB, Farias DR, Vaz JS, Brito A, Kac G, et al. Vitamin B-6 status in unsupplemented pregnant women is associated positively with serum docosahexaenoic acid and inversely with the n-6-ton-3 fatty acid ratio. J Nutr. 2017;147(2):170-8.

73 Trumbo PR, Wang JW. Vitamin B-6 status indices are lower in pregnant than in nonpregnant women but urinary excretion of 4-pyridoxic acid does not differ. J Nutr. 1993; 123(12):2137-41.
74 Skarupski KA, Tangney C, Li H, Ouyang B, Evans DA, Morris MC. Longitudinal association of vitamin B-6, folate, and vitamin B-12 with depressive symptoms among older adults over time. Am J Clin Nutr. 2010;92(2):330-5.

75 Cui R, Iso H, Date C, Kikuchi S, Tamakoshi A. Dietary folate and vitamin B6 and B12 intake in relation to mortality from cardiovascular diseases: Japan collaborative cohort study. Stroke. 2010;41(6):1285-9.

76 Hughes CF, Ward M, Tracey F, Hoey L, Molloy AM, Pentieva $\mathrm{K}$, et al. B-vitamin intake and biomarker status in relation to cognitive decline in healthy older adults in a 4-year follow-up study. Nutrients. 2017;9(1):53

77 Qin B, Xun P, Jacobs DR, Zhu N, Daviglus $\mathrm{ML}$, Reis JP, et al. Intake of niacin, folate, vitamin B-6, and vitamin B-12 through young adulthood and cognitive function in midlife: the Coronary Artery Risk Development in Young Adults (CARDIA) study. Am J Clin Nutr. 2017;106(4):1032-40.

78 Morris MS, Sakakeeny L, Jacques PF, Picciano MF, Selhub J. Vitamin B-6 intake is inversely related to, and the requirement is affected by, inflammation status. J Nutr. 2010;140(1): 103-10.

79 Larsson SC, Orsini N, Wolk A. Vitamin B6 and risk of colorectal cancer: a meta-analysis of prospective studies. JAMA. 2010;303(11): 1077-83.

80 Mocellin S, Briarava M, Pilati P. Vitamin B6 and cancer risk: a field synopsis and metaanalysis. J Natl Cancer Inst. 2017;109(3):1-9.

$81 \mathrm{Wu} \mathrm{W}$, Kang S, Zhang D. Association of vitamin B6, vitamin B12 and methionine with risk of breast cancer: a dose-response metaanalysis. Br J Cancer. 2013;109(7):1926-44.

82 Balk EM, Raman G, Tatsioni A, Chung M, Lau J, Rosenberg IH. Vitamin B6, B12, and folic acid supplementation and cognitive function: a systematic review of randomized trials. Arch Intern Med. 2007;167(1):21-30.

83 Green TJ, McMahon JA, Skeaff CM, Williams SM, Whiting SJ. Lowering homocysteine with $B$ vitamins has no effect on biomarkers of bone turnover in older persons: a 2-y randomized controlled trial. Am J Clin Nutr. 2007;85(2):460-4.

84 Aisen PS, Schneider LS, Sano M, Diaz-Arrastia R, van Dyck CH, Weiner MF, et al. Highdose $\mathrm{B}$ vitamin supplementation and cognitive decline in Alzheimer disease: a randomized controlled trial. JAMA. 2008;300(15): 1774-83.

85 Ford AH, Flicker L, Thomas J, Norman P, Jamrozik K, Almeida OP. Vitamins B12, B6, and folic acid for onset of depressive symptoms in older men: results from a 2-year placebo-controlled randomized trial. J Clin Psychiatry. 2008;69(8):1203-9.

86 Myung SK, Ju W, Cho B, Oh SW, Park SM, Koo BK. Efficacy of vitamin and antioxidant supplements in prevention of cardiovascular disease: systematic review and meta-analysis of randomised controlled trials. BMJ. 2013; 346:f10.
87 Yu J-TLi M-M, Wang H-F, Jiang T, Wang J, Meng X-F, et al. Efficacy of vitamins B supplementation on mild cognitive impairment and Alzheimer's disease: a systematic review and meta-analysis. Curr Alzheimer Res. 2014; 11(9):844-52.

88 Okereke OI, Cook NR, Albert CM, van Denburgh M, Buring JE, Manson JE. Effect of long-term supplementation with folic acid and $B$ vitamins on risk of depression in older women. Br J Psychiatry. 2015;206(4):324-31.

89 Zhang D-M, Ye J-X, Mu J-S, Cui X-P. Efficacy of vitamin $B$ supplementation on cognition in elderly patients with cognitive-related diseases. J Geriatr Psychiatry Neurol. 2017;30(1): 50-9.

90 IOM (Institute of Medicine). Dietary reference intakes for thiamin, riboflavin, niacin, vitamin B6, folate, vitamin B12, pantothenic acid, biotin, and choline. Washington, DC: National Academies Press; 1998.

91 WHO (World Health Organization), FAO (Food and Agriculture Organization). Vitamin and mineral requirements in human nutrition. 2nd ed. Bangkok: WHO; 2004.

92 Krems C, Walter C, Heuer T, Hoffmann I. Lebensmittelverzehr und Nährstoffzufuhr Ergebnisse der Nationalen Verzehrsstudie II. 12. Ernährungsbericht 2012. Bonn: Deutsche Gesellschaft für Ernährung; 2012. p. 40-85.

93 MRI (Max Rubner-Institut, Bundesforschungsinstitut für Ernährung und Lebensmittel): Bundeslebensmittelschlüssel. Karlsruhe, MRI (Max Rubner-Institut, Bundesforschungsinstitut für Ernährung und Lebensmittel), 2005-2014 [cited 2019 Sep 13]. Available from: www.blsdb.de.

94 Australian Government Department of Health. Methodological framework for the review of Nutrient Reference Values. Canberra: Australian Government Department of Health; 2017 [cited 2017 Oct 18]. Available from: https://www.nrv.gov.au/sites/default/ files/content/resources/MethodologicalFramework07032017CC4_0\%284\%29.pdf.

95 EFSA. Dietary reference values for nutrients: summary report. EFSA Supporting Publications; 2017. p. e15121.

96 Deutsche Gesellschaft für Ernährung: DGExpert, Version 1.8.10. (BLS 3.02). Bonn, 2017.

97 Mensink G, Schienkiewitz A, Haftenberger M, Lampert T, Ziese T, Scheidt-Nave C. Übergewicht und Adipositas in Deutschland: Ergebnisse der Studie zur Gesundheit Erwachsener in Deutschland (DEGS1). Bundesgesundheitsbl. 2013;56(5-6):786-94.

98 Robert Koch-Institut (RKI). Referenzperzentile für anthropometrische Maßzahlen und Blutdruck aus der Studie zur Gesundheit von Kindern und Jugendlichen in Deutschland (KiGGS) 2003-2006. Gesundheitsberichterstattung des Bundes. Berlin, 2011.

99 WHO (World Health Organization). WHO child growth standards - length/height-forage, weight-for-age, weight-for-length, weight-for-height and body mass index-forage. Genf: WHO; 2006. 